\title{
Sistem Informasi Geografis Berbasis Web Untuk Pemetaan Lokasi Pelatihan Sepakbola Di Kota Malang Menggunakan ArcGIS
}

\author{
Risdianto*1, Gita Indah Marthasari ${ }^{2}$, Wildan Suharso ${ }^{3}$ \\ 1,2,3Teknik Informatika/Universitas Muhammadiyah Malang \\ risdianto567@gmail.com¹ , gita@umm.ac.id ${ }^{2}$, wsuharso@umm.ac.id ${ }^{3}$
}

\begin{abstract}
Abstrak
Dalam meningkatkan prestasi dan kualitas sepakbola Indonesia dibutuhkan pembinaan pemain sepakbola dari mulai usia muda. Pembinaan yang baik maka akan memiliki fisik, mental serta taktik permainan yang baik pula. Pembinaan ini dapat dilakukan pada sekolah sepakbola di tiap-tiap daerah. Dalam hal pembinaan pemain sepakbola Kota Malang memiliki 29 sekolah sepakbola yang tersebar di tiap-tiap kecamatan, akan tetapi dari jumlah sekolah sepakbola tersebut hanya beberapa yang diketahui oleh masyarakat secara umum. Sistem informasi geografis mampu mengatasi permasalahan tersebut dengan cara melakukan pencarian persebaran sekolah sepakbola pada tiap kecamatan di kota Malang. Sedangkan SIG berbasis web mampu memberikan informasi secara lengkap kepada masyarakat dengan mengaksesnya secara online melalui jaringan internet. Penelitian ini merancang aplikasi SIG yang dapat dijalankan pada web browser dengan memberikan informasi tentang persebaran sekolah sepakbola pada tiap kecamatan beserta informasi lengkap. Dalam perancangannya dibutuhkan metode pengumpulan data yaitu data spasial dan data non spasial/atribut. Data spasial berupa lokasi sekolah sepakbola yang ditunjukkan pada peta Kota Malang yang di dapatkan dari alamat lengkap sekolah sepakbola. Sedangkan data non spasial terdiri dari nama sekolah sepakbola, nama kordinator, nomor telepon, jadwal latihan, tempat latihan, syarat masuk klub dan jumlah anggota. Pada perancangan SIG berbasis web ini juga dilengkapi dengan fitur lain yaitu pengelolaan lapangan dan pengelolaan event.
\end{abstract}

Kata Kunci: Sekolah sepakbola, SIG, SIG berbasis Web, Data Spasial, Data Non Spasial

\begin{abstract}
In improving the achievement and quality of Indonesian football soccer players needed coaching from a young age. A good coaching will have a good physical, mental and tactical game as well. This guidance can be done at football schools in each region. In terms of coaching football players Malang City has 29 football schools spread across each district, but from the number of school football is only a few that are known by the public in general. Geographic information system able to overcome these problems by way of searching school football distribution in each district in Malang city. While web-based GIS is able to provide complete information to the community by accessing it online through the internet network. This study designs GIS applications that can be run on a web browser by providing information about the distribution of football schools in each district along with complete information. In the design required data collection methods are spatial data and non spatial data / attributes. Spatial data in the form of football school location shown on the map of the city of Malang obtained from the full school football address. Non spatial data consists of the name of the football school, the name of the coordinator, the telephone number, the training schedule, the training ground, the club entry requirements and the number of members. In the design of web-based GIS is also equipped with other features of field management and event management.
\end{abstract}

Keywords: School soccer, GIS, WebGIS, Spatial Data, Non Spatial Data

\section{Pendahuluan}

Pada saat ini olahraga telah menjadi trend gaya hidup yang sangat digemari oleh seluruh masyarakat Indonesia setelah Kementerian pemuda dan Olahraga mengkampanyekan gerakan"Ayo Olahraga" melalui akun istagramnya. Bahkan, salah satu olahraga yang mendapat respon paling banyak dari masyarakat indonesia adalah sepakbola [1]. Hingga kini sepakbola 
menjadi olahraga terkenal dengan antusiasme penggemarnya di seluruh penjuru dunia, hal ini dibuktikan dengan mudahnya permainan sepakbola dapat dijumpai di desa maupun dikota [2].

Sepakbola mulai masuk ke Indonesia pada tahun 1914 pada masa penjajahan oleh pemerintah Hindia Belanda. Pada tahun 1930 Indonesia mendirikan Persatuan Sepakbola Seluruh Indonesia yang disingkat menjadi PSSI. Dengan di dirikannya PSSI, Tim Nasional indonesia telah banyak meraih prestasi. Salah satu prestasi yang membanggakan yaitu pertama kali mewakili sepakbola asia yang ikut ajang kompetisi di FIFA World Cup pada tahun1938 di Prancis [3].

Sejalan dengan perkembangan sepakbola dunia, Prestasi sepakbola indonesia sekarang ini tidak seperti prestasi sepakbola yang ditorehkan pada masa sebelumnya. Untuk memperbaiki prestasi dan kualitas sepakbola indonesia, dibutuhkan kerjasama antara PSSI dengan pengelola klub-klub sepakbola ditiap-tiap daerah untuk pembinaan pemain-pemain muda.

Salah satu daerah yang berpotensial melakukan pembinaan pemain sepakbola usia muda adalah Kota Malang. Kota Malang yang berada di Provinsi Jawa Timur dengan suhu udara ratarata berkisar antara $22,7^{\circ} \mathrm{C}-25,1^{\circ} \mathrm{C}$ dimana kondisi ini adalah kondisi yang sangat ideal untuk proses berlatih sepak bola karena cuaca tidak terlampau panas dan tidak terlampau dingin [4].

Selain di pengaruhi faktor iklim Kota Malang juga konsisten mengikuti perkembangan sepakbola nasional. Sehingga, Kota Malang dikenal sebagai salah satu kiblatnya persepakbolaan nasional. Hal ini dibuktikan dengan adanya klub-klub sepakbola profesional diantaranya Arema FC, Persekam Metro FC, Persikoba Batu dan Persema Malang. Salah satu klub sepabola yang menjadi bukti adalah Arema FC yang telah menjuarai liga-liga dilndonesia dari tahun 1992 sampai dengan tahun 2017 [5]. Keberadaan Arema FC tidak terlepas dari pemain-pemain muda asli kota Malang yang memulai latihannya dari usia dini di salah satu sekolah sepakbola. Sekolah sepakbola inilah yang menjadi titik awal seorang calon atlet sepakbola menjadi pemain Profesional yang memiliki fisik, mental serta taktik permainan yang baik.

Berdasarkan data dari PSSI Kota Malang, terdapat 29 sekolah sepakbola (SSB) Kota Malang yang berada di bawah naungan PSSI Kota Malang. Namun dari sekian banyak SSB yang terdata tidak semua SSB diketahui oleh seluruh masyarakat Malang, Karena data dari PSSI Kota Malang hanya sebatas data daftar klub dan belum adanya data yang jelas secara geografis mengenai lokasi pelatihan dan informasi penunjang lainnya. Untuk mengatasi permasalahan tersebut maka dibutuhkan Sistem Informasi Geografis (SIG) agar dapat memberikan solusi dari permasalahan tersebut. Dengan adanya SIG nantinya diharapkan informasi tentang pemetaan sekolah sepakbola di Kota Malang dapat di sampaikan dalam bentuk visual kepada masyarakat khususnya bagi para calon atlet.

Pembangunan SIG merupakan langkah yang tepat untuk mengatasi permasalahan dalam menemukan tempat pelatihan sepakbola. selain itu juga dapat membantu PSSI Kota Malang dalam pengelolaan data sekolah sepakbola [6]. Solusi tersebut didasarkan pada kemampuan SIG yang dapat bekerja dengan data yang tereferensi secara spasial dan mampu menganalisanya, dimana kemampuan ini dapat memberikan gambaran yang lebih komprehensif dibanding dengan sistem informasi yang berbasis statistik [7].

Menggabungkan teknologi SIG dan web kedalam aplikasi sistem informasi geografis memungkinkan informasi lokasi SSB dan kelebihan setiap SSB dapat divisualisasikan ke dalam web. Penggabungan teknologi tersebut dapat memberikan informasi yang dapat diakses secara umum tanpa ada batasan tempat dan waktu [8].

Dengan memperhatikan permasalahan tersebut dan melihat manfaat sistem informasi geografis yang begitu besar, maka perlu dilakukan penelitian dan pembuatan sebuah sistem berbasis web yang nantinya akan dapat memetakan persebaran lokasi pelatihan sepakbola di kota Malang.

\section{Metode Penelitian}

\subsection{Pengumpulan data}

Pada perancangan sistem informasi geografis dibutuhkan pengumpulan data untuk menentukan lokasi pada suatu peta. pengumpulan data pada sistem ini di lakukan di kantor Persatuan Sepakbola Seluruh Indonesia (PSSI) Kota Malang dan observasi langsung pada tiaptiap SSB untuk mendapatkan data yang lengkap. Data yang dibutuhkan dalam sistem ini yaitu data spasial dan data atribut. Data spasial berupa lokasi tempat pelatihan yang ditunjukkan dengan peta kota Malang dan layer lokasi. Sedangkan, data non spasial terdiri dari data nama 
SSB, alamat sekretariat, nama kordinator, nomor telepon, jadwal latihan, tempat latihan, syarat masuk klub dan jumlah anggota.

\subsection{Perancangan Sistem}

\subsubsection{Arsitektur Sistem}

Arsitektur sistem menggambarkan hubungan aliran data antara sistem dengan kesatuan luar. Gambar 1 berikut ini arsitektur sistem pada sistem informasi geografis berbasis web untuk pemetaan lokasi pelatihan sepakbola menggunakan ArcGIS dengan layanan Open Street Map untuk Petanya.

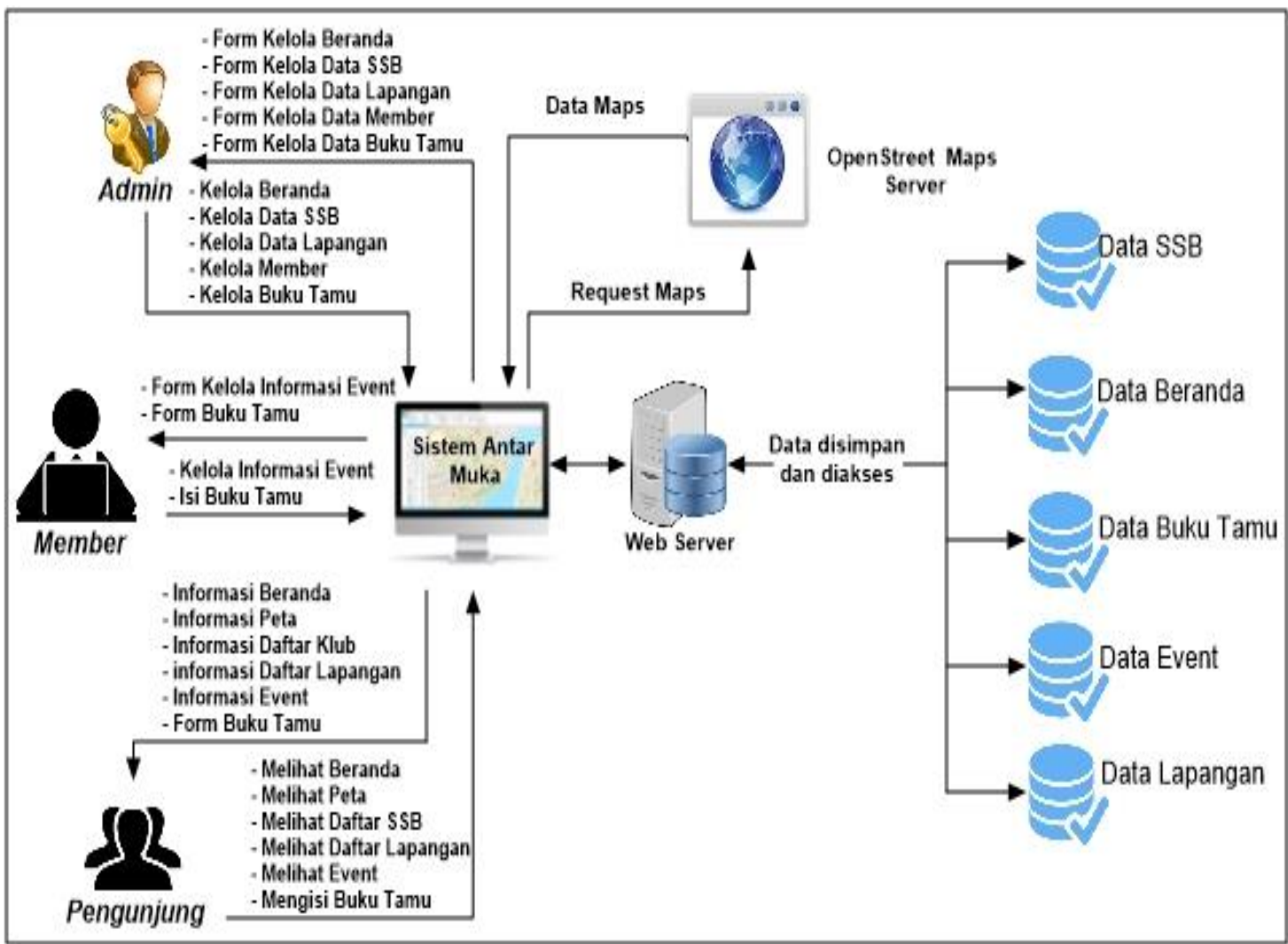

Gambar 1. Arsitektur Sistem

Arsitektur sistem pada Gambar 1 memiliki 3 entitas luar yaitu pengunjung yaitu pengguna yang dapat mengakses sistem secara langsung, member yaitu pengguna yang dapat melakukan pengelolaan event dan admin yaitu pengguna yang dapat melakukan pengelolaan keseluruhan sistem. Pada sistem pengunjung terdapat alir data yaitu data beranda, data peta, data SSB, data lapangan, data event, dan data buku tamu. Pada sistem member terdapat alir data yaitu data event dan data buku tamu. Sedangkan pada sistem admin terdapat alir data diantaranya data beranda, data SSB, data lapangan, data member dan data buku tamu.

\subsubsection{Data Flow Diagram}

Data Flow Diagram(DFD) Level 0 pada Gambar 2 menggambarkan arus data yang berfungsi untuk memudahkan pengguna dalam memahami sistem secara logika dan terstruktur. DFD juga menggambarkan dari mana asal dan tujuan data yang digunakan pada sistem. Berikut DFD level 0 yang digunakan pada informasi geografis berbasis web untuk pemetaan lokasi pelatihan sepakbola menggunakan arcGIS.

Pada DFD level 0 terdapat enam proses yaitu proses olah beranda, proses olah data SSB, proses olah data lapangan, proses olah data event, proses olah member, proses olah buku tamu. 


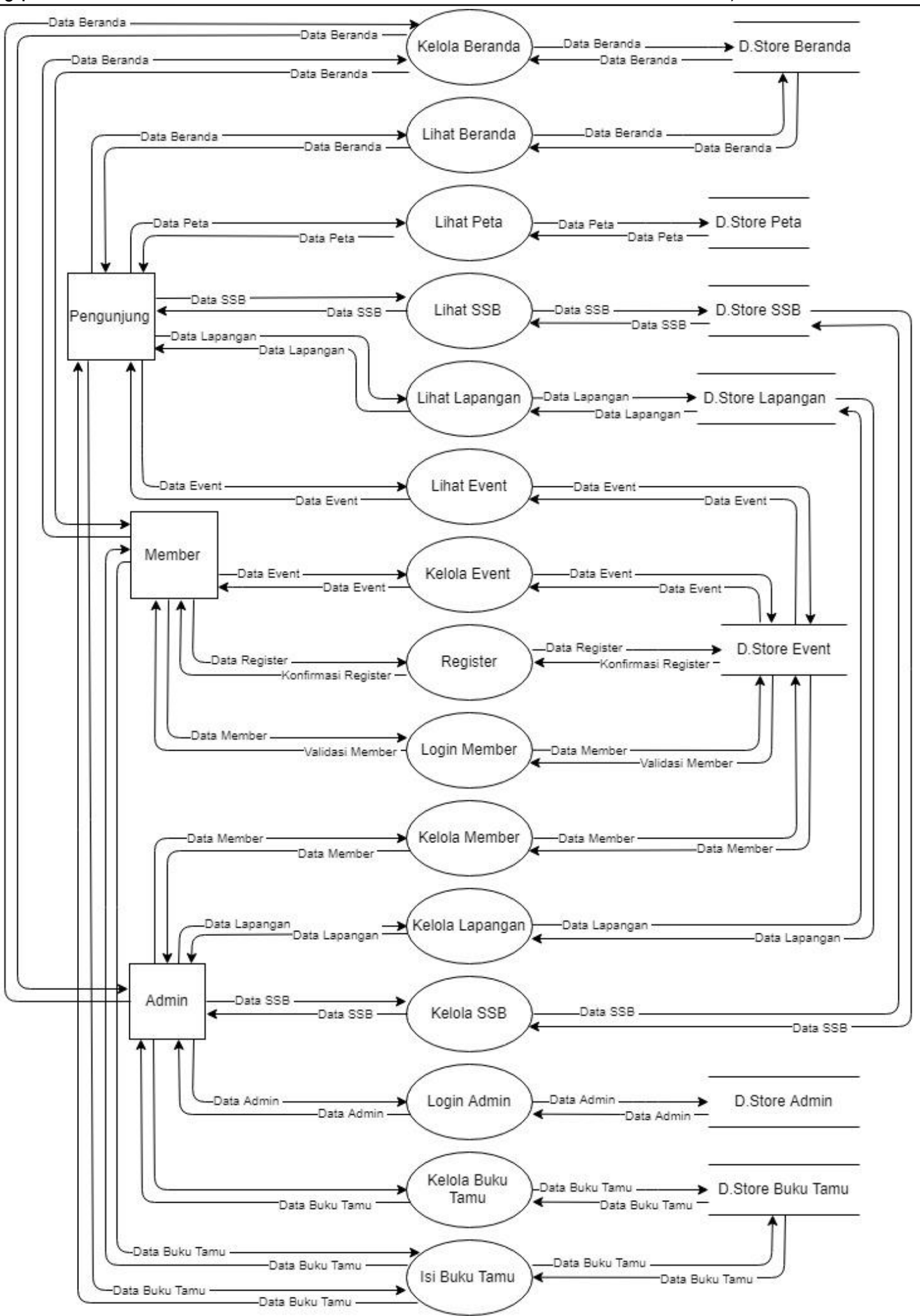

Gambar 2. Data Flow Diagram SIG untuk Pemetaan Lokasi Pelatihan Sepakbola

\subsubsection{Flowchart}

Flowchart merupakan penjelasan proses jalannya sistem informasi geografis di web pada pemetaan lokasi pelatihan sepakbola. Proses jalannya sistem dapat dijelaskan pada Gambar 3 berikut.

REPOSITOR, Vol. 2, No. 6, Juni 2020: 701-710 


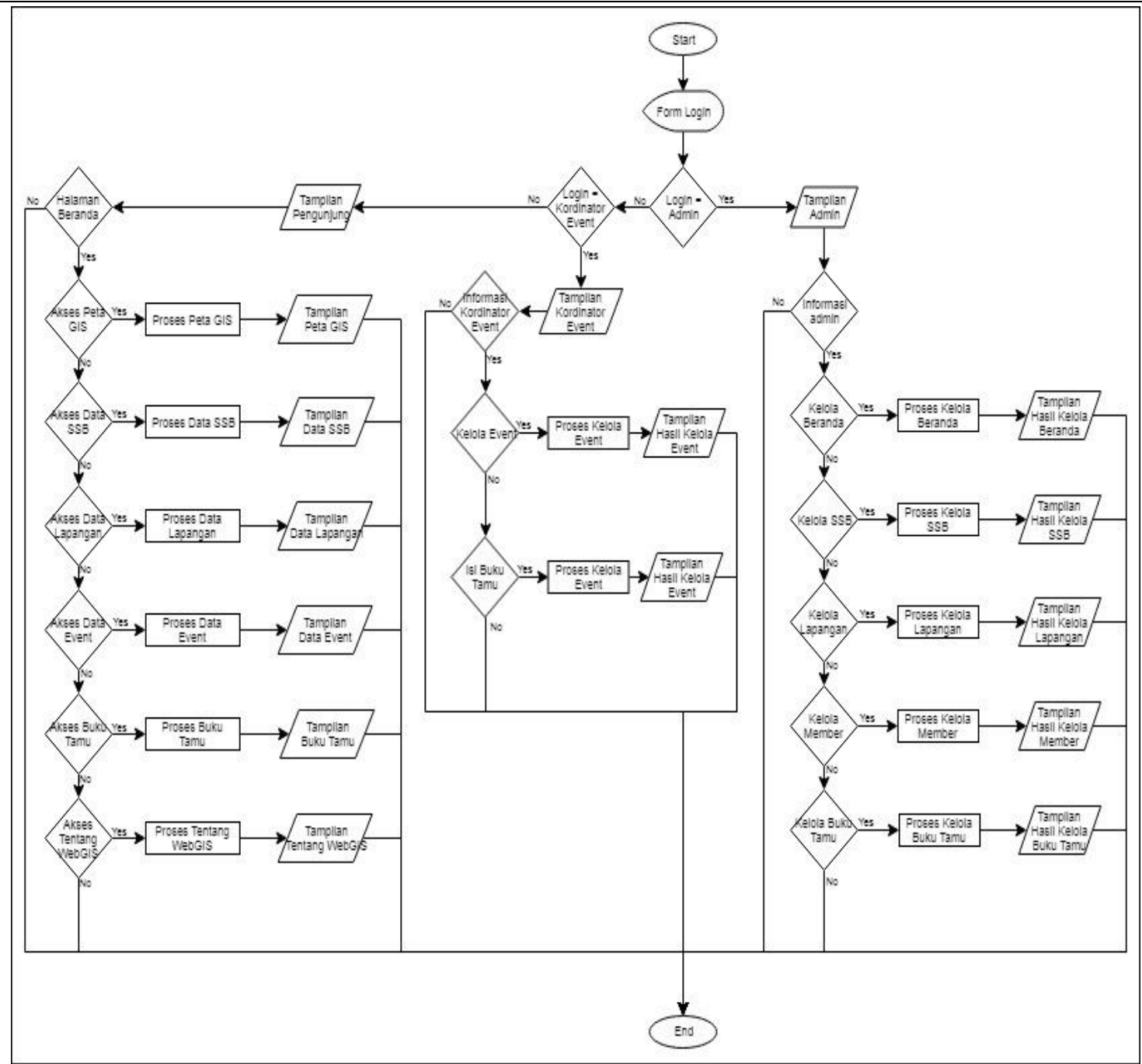

Gambar 3. Flowchart

Pada Gambar 3 tersebut dapat menunjukkan urutan proses secara mendetail dan hubungan suatu proses dengan proses lainnya. Flowchart ini juga menjelaskan proses jalannya sistem pengunjung, sistem member dan sistem admin hingga selesai.

\section{Hasil Penelitian dan Pembahasan}

Hasil penelitian ini dilakukan dengan menerapkan hasil rancangan dari pembahasan sebelumnya. Berdasarkan perancangannya tampilan web di bagi menjadi tiga bagian, yaitu tampilan pengunjung, tampilan member dan tampilan admin. pada tampilan pengunjung berisi menu yang dapat diakses secara langsung oleh pengunjung. pada tampilan member berisi menu untuk pengelolaan event yang diakses oleh member dengan melakukan login setelah divalidaasi oleh admin. Pada tampilan admin berisi menu pengelolaan keseluruhan sistem yang diakses dengan melakukan proses login. Hasil penelitian dari tiga tampilan pengguna sistem dapat dijelasankan sebagai berikut.

\subsection{Tampilan Pengunjung}

\subsubsection{Beranda}

Pada gambar 4 tersebut merupakan tampilan awal pada saat pengunjung pertama kali mengakses sistem. Selain sebagai tampilan utama tampilan beranda ini juga digunakan untuk melihat informasi event atau informasi lainnya mengenai web ini. 


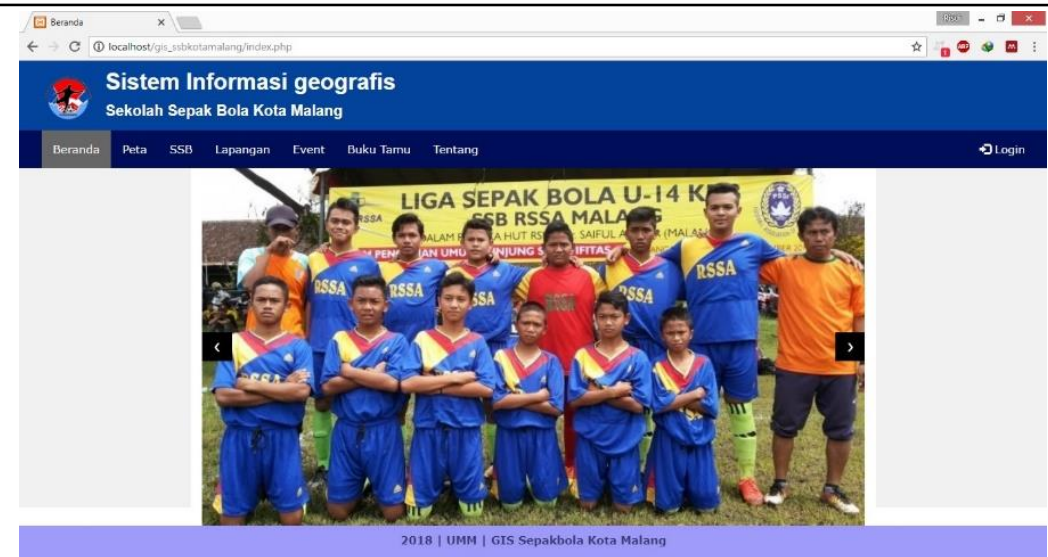

Gambar 4. Tampilan Beranda Pengunjung

\subsubsection{Peta}

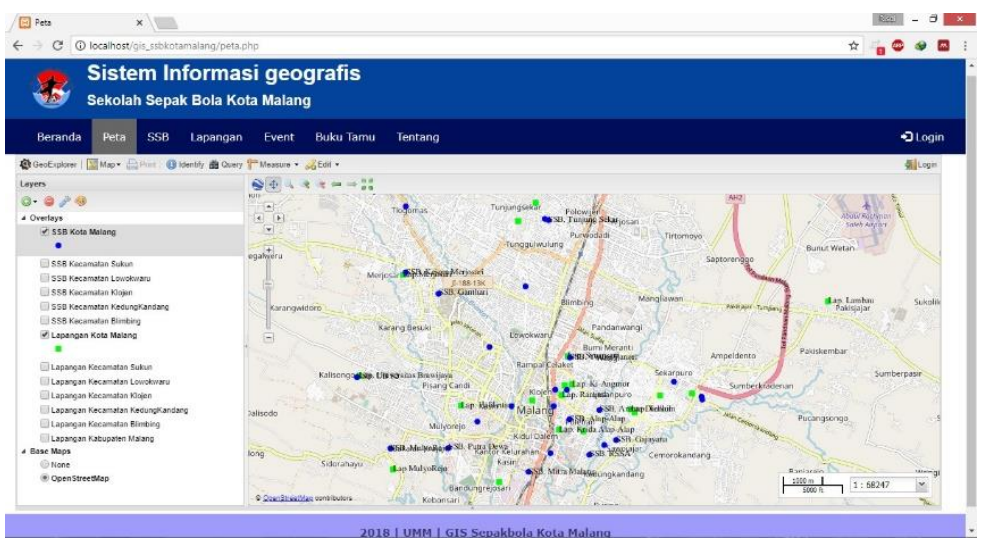

Gambar 5. Tampilan Peta GIS

Pada Gambar 5 tersebut merupakan tampilan yang digunakan untuk melihat persebaran sekolah sepakbola dan lapangan Kota Malang berdasarkan data Kecamatan. Proses melihat persebaran dan pencarian lokasi ini dilakukan dengan mengklik tombol ceklis yang diinginkan.

\subsubsection{Data SSB}

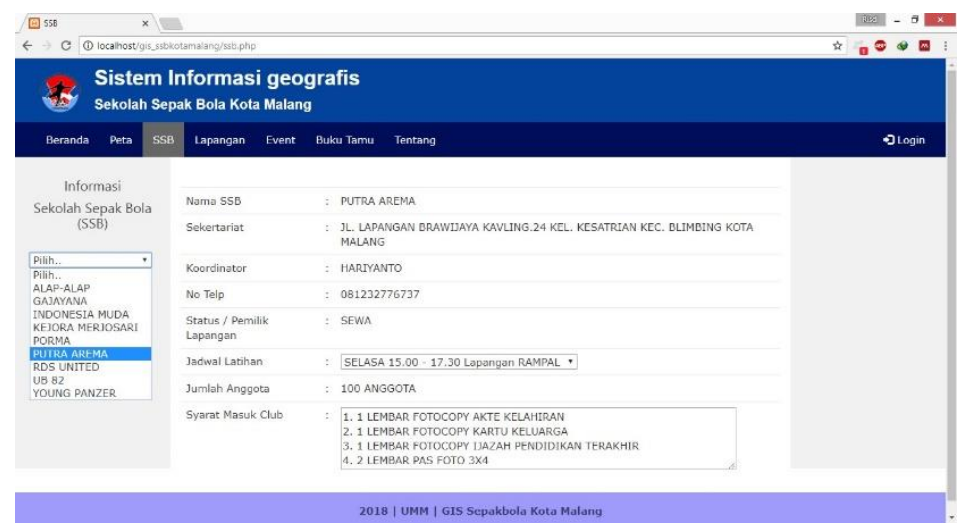

Gambar 6. Daftar SSB

Pada Gambar 6 tersebut merupakan tampilan yang digunakan untuk melihat daftar sekolah sepakbola lengkap dengan informasinya, diantaranya nama SSB, sekretariat, koordinator, nomor telepon, status pemilikan lapangan, jadwal latihan, jumlah anggota dan syarat masuk SSB.

REPOSITOR, Vol. 2, No. 6, Juni 2020: 701-710 


\subsubsection{Data Lapangan}

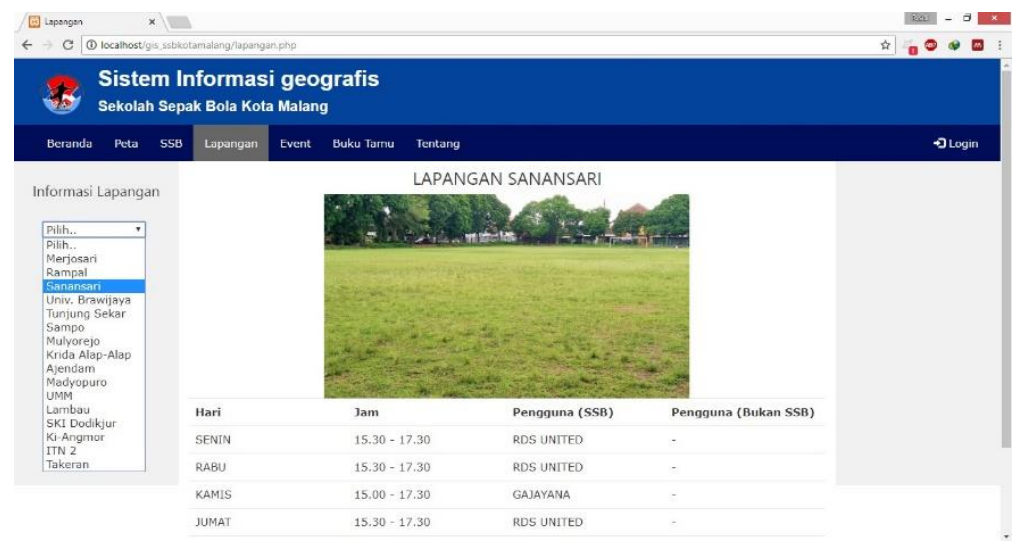

Gambar 7. Data Penggunaan Lapangan

Pada Gambar 7 tersebut merupakan tampilan yang digunakan untuk melihat daftar lapangan beserta informasinya jadwal pemakaiannya, diantaranya hari, jam, pengguna.

\subsubsection{Data Event}

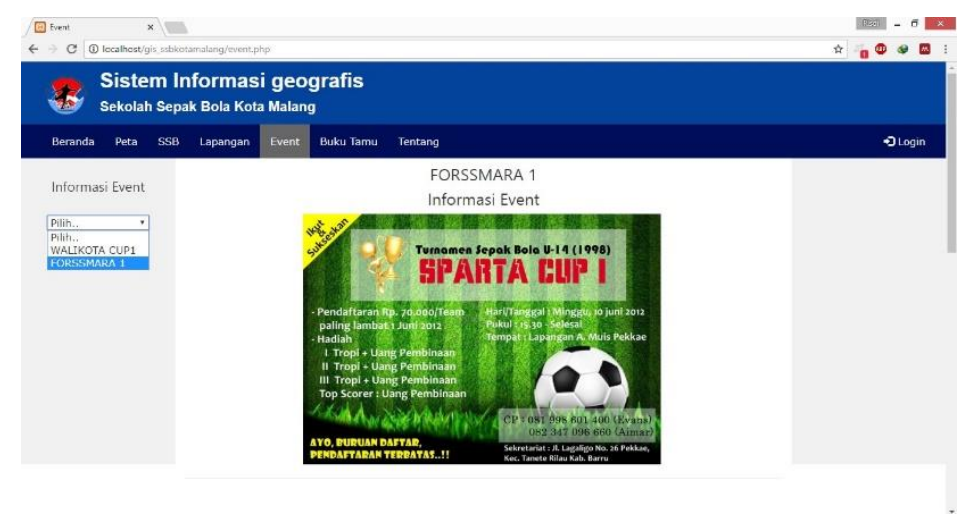

Gambar 8. Data Event

Pada Gambar 8 tersebut merupakan tampilan yang digunakan untuk melihat daftar dan informasi event yang akan berlangsung atau sedang berlangsung. Pada menu ini terdapat beberapa informasi diantaranya informasi tentang event yang akan diadakan, formulir pendaftaran, informasi jadwal pertandingan dan informasi hasil pertandingan.

\subsection{Tampilan Member}

3.2.1 Kelola Event

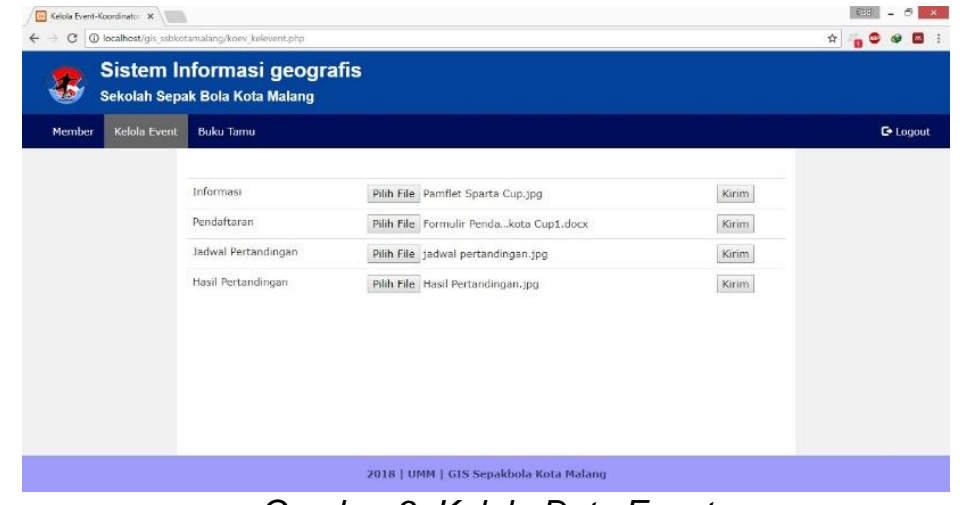

Gambar 9. Kelola Data Event 
Pada Gambar 9 tersebut merupakan tampilan yang digunakan untuk mengirimkan data tentang informasi event yang akan diadakan atau event yang sedang berlangsung. Data yang dikirimkan diantaranya informasi pelaksanaan, formulir pendaftaran, jadwal pertandingan dan hasil pertandingan. Kemudian, Data yang di kirimkan akan tampil pada menu event di interface pengunjung.

\subsection{Tampilan Admin}

\subsubsection{Kelola Beranda}

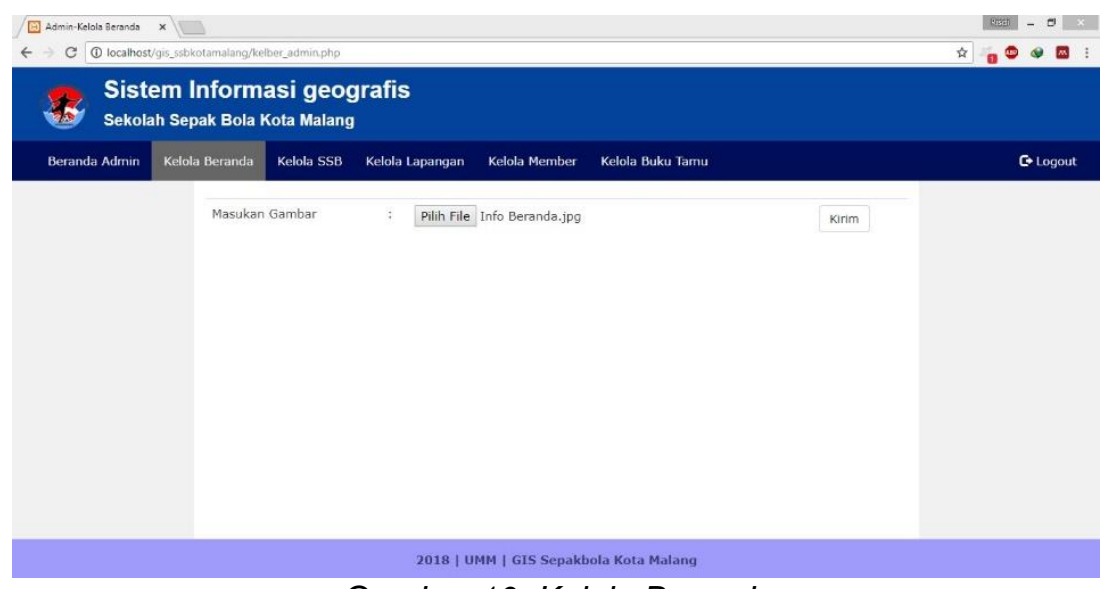

Gambar 10. Kelola Beranda

Pada Gambar 10 tersebut merupakan tampilan yang digunakan untuk mengirimkan data tentang informasi penting. Data yang di kirimkan tersebut akan tampil pada menu beranda di interface pengunjung.

\subsubsection{Kelola SSB}

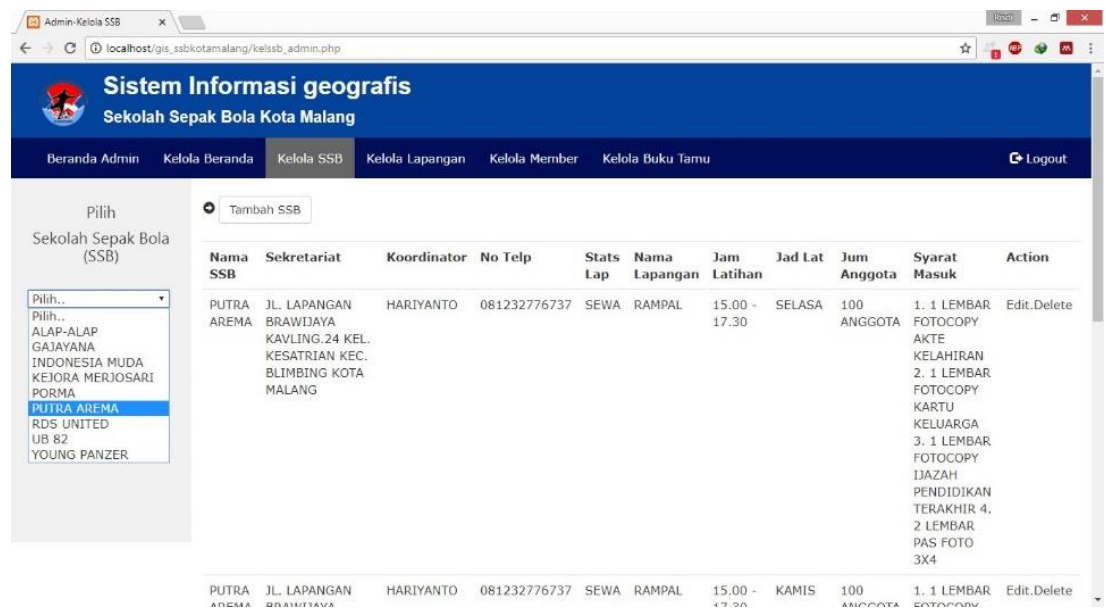

Gambar 11. Kelola Data SSB

Pada Gambar 11 tersebut merupakan tampilan yang digunakan untuk proses kelola data SSB yang sudah terdaftar pada sistem. Proses kelola ini dapat dilakukan dengan edit data, tambah data dan hapus data. Data yang dikelola tersebut akan tampil pada menu SSB dan lapangan di interface pengunjung.

\subsubsection{Kelola Jadwal Pemakaian Lapangan}

Pada Gambar 12 tersebut merupakan tampilan yang digunakan untuk proses kelola jadwal pemakaian lapangan dari lapangan yang sudah terdaftar. Proses kelola ini dapat dilakukan dengan tambah jadwal pemakaian, edit pemakaian hingga hapus pemakaian. Data yang dikelola tersebut akan tampil pada menu lapangan di interface pengunjung.

REPOSITOR, Vol. 2, No. 6, Juni 2020: 701-710 


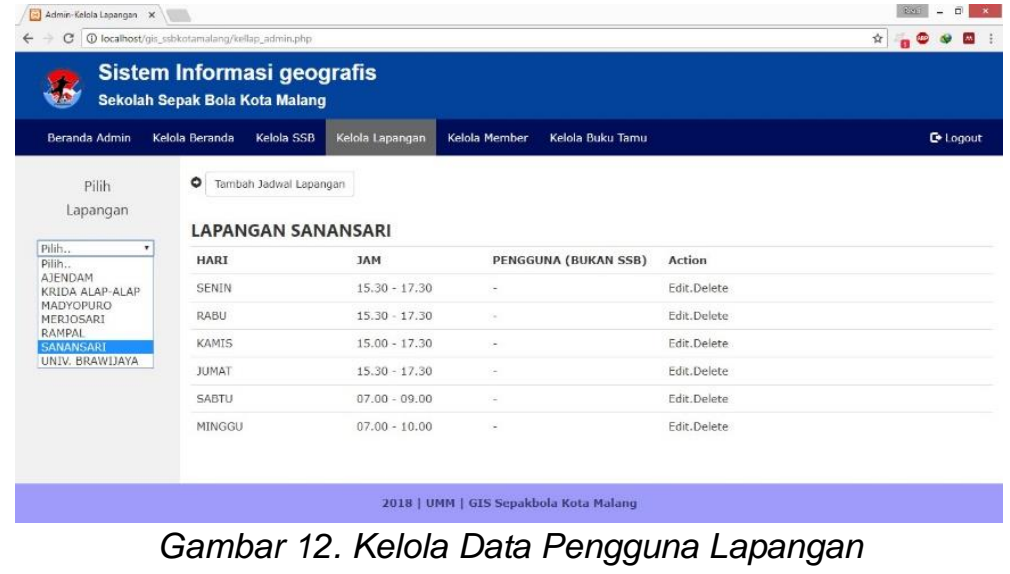

\subsubsection{Kelola Member}

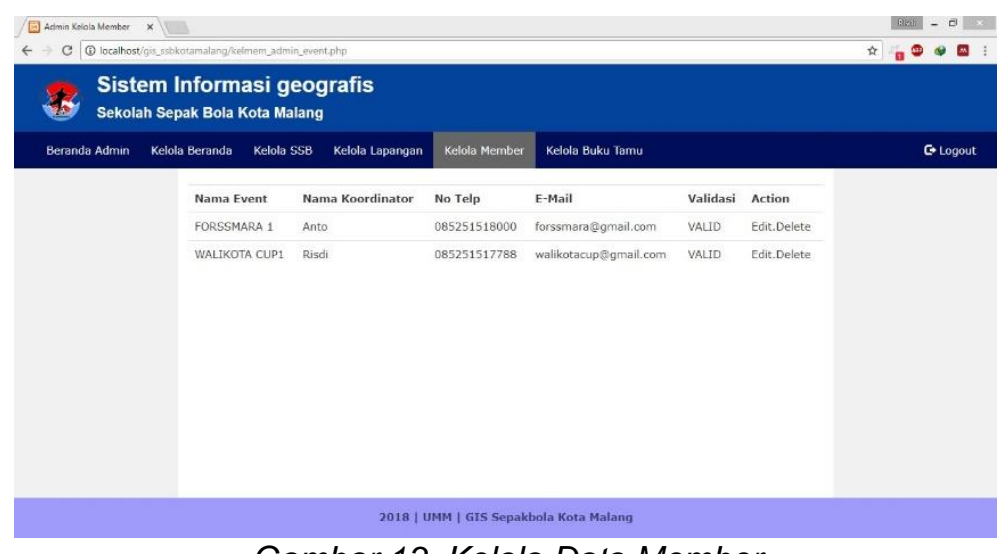

Gambar 13. Kelola Data Member

Pada Gambar 13 tersebut merupakan tampilan yang digunakan untuk proses kelola daftar member yang sudah terdaftar di sistem. Proses kelola ini dapat dilakukan dengan melakukan validasi member dan hapus member. Validasi member dilakukan untuk mensetujui adanya pendaftaran member baru yang akan melakukan pengelolaan event.

\section{Kesimpulan dan saran}

Kesimpulan dari penelitian yang telah dilakukan dan saran untuk pengembang yaitu sebagai berikut:

\subsection{Kesimpulan}

1. Dalam penelitian ini, sekolah sepakbola Kota Malang tedata berjumlah 29 SSB yang di dapatkan dari kantor persatuan sepakbola Seluruh Indonesia (PSSI) Kota Malang dan terjun langsung ke tiap-tiap sekolah sepakbola.

2. Masyarakat atau calon atlet sebagai pengunjung WebGIS dapat mengetahui persebaran lokasi dan informasi yang lebih efisien mengenai lokasi sekolah sepakbola di Kota Malang.

3. Sistem yang dibuat dapat menampilkan peta dan lokasi SSB beserta lapangan sepakbola.

\subsection{Saran}

1. Sistem ini dapat dikembangkan lagi dengan menambahkan fitur-fitur lain yang mendukung.

2. Dapat menambahkan data SSB untuk wilayah Kabupaten Malang dan Kota Batu beserta data lapangan sepakbola yang belum terdata.

\section{Referensi}

[1] Juara.net, Kemenpora Bentuk Gerakan "Ayo Olahraga" unntuk dukung Asian Games 2018. Diambil kembali dari Juara.net: https://juara.bolasport.com, 2018.

[2] J. Luxbaucher, Sepak Bola Taktik dan Teknik bermain (Alih bahasa Bambang Sugeng). Jakarta: PT Grafindo Persada, 2004 
[3] Sejarah PSSI, Diambil kembali dari PSSI: https://www.pssi.org/news/sejarah-pssi, 2012.

[4] Geografis, Diambil kembali dari Pemerintah Kota Malang: https://malangkota.go.id, 2018.

[5] H. Kertapati, Bukan Cuma Arema FC, Tapi Malang Ternyata Juga Punya 8 Klub Lain Yang Tak Kalah Menarik Untuk Disimak. Diambil kembali dari Striker.ID: https://www.striker.id, 2018.

[6] S. T. Yuliani, Aplikasi Sistem Informasi Geografis(SIG) Untuk Pemetaan Pasar Tradisional di Kota Semarang Berbasis Web. Jurnal Geodesi Undip, 2016.

[7] D. Charter, Desain dan Aplikasi GIS. Jakarta: PT. Elex Media Komputindo, 2004.

[8] P. K. A. Krisna, I. N. Priasa, and P. W. Buana, Sistem Informasi Geografis Pemetaan Penyebaran Penyakit Berbasis Web, Jurnal Teknologi Informasi, Vol.2, No.3, 2014. 